\title{
Viral surveillance and the 1968 Hong Kong flu pandemic ${ }^{\dagger}$
}

\author{
Robert Peckham \\ Centre for the Humanities and Medicine, University of Hong Kong, Centennial Campus, Pokfulam, Hong Kong \\ Corresponding author. E-mail: rpeckham@hku.hk
}

\begin{abstract}
This article traces the diffusion of the 1968 Hong Kong influenza pandemic against the backdrop of scientific and global health developments, a global wave of social protests, and Cold War tensions between the United States and the People's Republic of China. Although the outbreak was far less severe than the 1918-19 'Spanish' influenza pandemic, the ease with which influenza spread globally between 1968 and 1970 contributed to a reformulation of global health that emphasized the need for enhanced preparedness and rapid vaccine production. From the 1950s through the 1960s, the scope of disease surveillance expanded, with China increasingly identified as the global epicentre of viral threats. In so arguing, the article challenges histories of global health that suggest that this was a period when concerns for infectious disease receded, in contrast to the final two decades of the twentieth century that saw the ascendancy of an 'emerging diseases worldview'.
\end{abstract}

Keywords: Cold War; global health; influenza; pandemic; People’s Republic of China; preparedness; surveillance

The 1968 Hong Kong influenza pandemic (hereafter the 'Hong Kong flu') was one of three influenza pandemics in the twentieth century. There is now a large and growing literature on the 1918-19 'Spanish' influenza pandemic that killed upwards of 50 million people - and possibly twice that number. ${ }^{1}$ Much less attention, however, has been paid to the 1957 Asian influenza pandemic and to the Hong Kong flu that killed an estimated one million people worldwide. ${ }^{2}$

The experience of the COVID-19 pandemic provides a useful vantage for re-evaluating the history of these twentieth-century influenza pandemics and their roles in the broader development of global health. ${ }^{3}$ In January 2020, during the coronavirus outbreak in China's central Hubei province, researchers and the international media drew frequent analogies between COVID-19 and the 2002-3 epidemic of severe acute respiratory syndrome (SARS). The two episodes appeared to have much in common, including the allegedly bungled responses by Chinese authorities, at least in the early stages. In both cases, evidence of human-to-human transmission was covered up, vital information was withheld from the international community, and

${ }^{\dagger} \mathrm{I}$ am grateful to David Arnold, Alison Bashford, and Ewout Frankema for their helpful feedback on an earlier version of this article. Thanks also to my colleagues Ria Sinha and Yang Xi Nancy at the Centre for the Humanities and Medicine, University of Hong Kong, in what are testing times. The research for this article was supported by a grant from the Research Grants Council of Hong Kong (HKU Project Code 17607415: 'Techno-Imperialism and the Origins of Global Health').

${ }^{1}$ N. P. A. S. Johnson and J. Mueller, 'Updating the Accounts: Global Mortality of the 1918-1920 "Spanish" Influenza Pandemic', Bulletin of the History of Medicine 76 (2002): 105-15; Jeffery K. Taubenberger and David M. Morens '1918 Influenza: The Mother of All Pandemics', Emerging Infectious Diseases 12, no. 1 (January 2006): 15.

${ }^{2}$ See Centers for Disease Control and Prevention, '1968 Pandemic (H3N2 Virus)', https://www.cdc.gov/flu/pandemicresources/1968-pandemic.html.

${ }^{3}$ On the dangers of analogizing between epidemic crises, however, see Robert Peckham, 'COVID-19 and the anti-lessons of history', Lancet 395, no. 10227 (14 March 2020): 850-2.

(c) The Author(s), 2020. Published by Cambridge University Press. 
'whistleblowers' were silenced. The genetic similarity between the viruses was recognized by the International Committee on Taxonomy of Viruses when it named the new virus SARS-CoV-2. ${ }^{4}$ However, as the Hubei outbreak expanded globally and the number of COVID-19 related deaths began to climb steeply - far exceeding the 774 deaths from SARS - the earlier analogy was dropped and comparisons were increasingly drawn with the 1918-19 influenza pandemic. ${ }^{5}$

A comparison with the Hong Kong flu provides another perspective on COVID-19, and an opportunity to reassess the history of twentieth- and twenty-first-century pandemic responses. Today, many commentators are speaking of a new Cold War between the United States and the People's Republic of China (PRC), noting the extent to which the COVID-19 pandemic is entangled in geopolitics. As China's foreign minister, Wang Yi, declared in March 2020, the ongoing US-China trade war and the Trump administration's politicization of the coronavirus repeatedly dubbed the 'Chinese virus', or a variant of this term - 'are taking China-US relations hostage and pushing our two countries to the brink of a new cold war' ${ }^{6}$

COVID-19 has not only unfolded against the backdrop of a US-China trade war, but within the context of intensifying rivalries in the South China Sea, anti-government protests and the imposition by Beijing of a new security law in Hong Kong, and race riots in the United States. Similarly, the Hong Kong flu occurred during Mao Zedong's Cultural Revolution (1966-76), the aftermath of anti-colonial riots in Hong Kong, the Vietnam War, and the Civil Rights movement in the United States. In 1968, Martin Luther King was assassinated, leading to widespread demonstrations and the imposition of curfews. Student protests erupted in cities across the world, and the reforms of the 'Prague Spring' were suppressed when the Soviet Union invaded Czechoslovakia in August 1968. Cold War geopolitics were integral to how the Hong Kong flu was understood, and to how epidemic preparedness came to be formulated as a strategy of pandemic pre-emption.

The late 1950s and the 1960s are often viewed as an interlude between scientific developments. As a recent paper puts it, 'The characteristics of the Hong Kong flu pandemic indicated a lack of progress in public health intervention strategies and medical science between the 1957 and 1968 pandemics. ${ }^{77}$ At the same time, the 1960s and 1970s tend to be regarded as a prelude to new concerns for infectious diseases in the final two decades of the century. Histories of science and medicine emphasize the 1980s and early 1990s as a watershed: this was, after all, the period when the term 'emerging infections' gained traction in the wake of the HIV/AIDS pandemic and the identification of other viral diseases, such as Ebola in $1976 .{ }^{8}$ As Nicholas King has argued, global disease prevention became embroiled in US geopolitical and economic calculations from the early 1990 s, giving rise to an 'emerging diseases worldview'.'

Implicit in such arguments is the idea that concerns about infectious diseases receded in the 1960s, a view encapsulated in the pronouncement misattributed to the US surgeon general, William H. Stewart, who reportedly declared in 1967: 'It is time to close the book on infectious

\footnotetext{
${ }^{4}$ A. E. Gorbalenya et al. 'The Species Severe Acute Respiratory Syndrome-Related Coronavirus: Classifying 2019-nCoV and Naming It SARS-CoV-2', Nature Microbiology 5, no. 4 (2020): 536-44, https://doi.org/10.1038/s41564-020-0695-z.

${ }^{5}$ See, for example, 'Pandemics Past and Present: A Peculiarity of Spanish Flu May Shed Light on COVID-19', Economist, 25 April 2020, https://www.economist.com/science-and-technology/2020/04/25/a-peculiarity-of-spanish-flu-may-shed-lighton-covid-19 and John Ashton, 'COVID-19 and the "Spanish" Flu', Journal of the Royal Society of Medicine (14 May 2020), https://doi.org/10.1177/0141076820924241. The World Health Organization categorized the COVID-19 outbreak as a pandemic on 11 March 2020.

${ }^{6}$ Simon Goodley and Dan Sabbagh, 'China Raises US Trade Tensions with Warning of "New Cold War"', Guardian, 24 May 2020, https://www.theguardian.com/world/2020/may/24/china-raises-us-trade-tensions-with-warning-of-new-cold-war.

${ }^{7}$ Patrick R. Saunders-Hastings and Daniel Krewski, 'Reviewing the History of Pandemic Influenza: Understanding Patterns of Emergence and Transmission', Pathogens 5, no. 4 (2016): 66, https://doi.org/10.3390/pathogens5040066.

${ }^{8}$ Joshua Lederberg, Robert E. Shope, and Stanley C. Oaks Jr., eds., Emerging Infections: Microbial Threats to Health in the United States (Washington, DC: Institute of Medicine, National Academy Press, 1992).

${ }^{9}$ Nicholas B. King, 'Security, Disease, commerce: Ideologies of Postcolonial Global Health', Social Studies of Science 32, no. 5/6 (2002): 763-89.
} 
diseases, and declare the war against pestilence won. ${ }^{10}$ This article challenges these interpretations and contributes to a reassessment of the 1968 pandemic; it argues that the 1960s saw significant developments in surveillance, virological science, and vaccine production. ${ }^{11}$ As Kilbourne has observed, the 1957 and 1968 pandemics took place 'in the era of modern virology' and as a result were 'most thoroughly characterized'. ${ }^{12}$ While the current article discusses the formation of this 'modern virology', it also considers the political assumptions, interests, and priorities that shaped and continue to shape - the practices and institutions of pandemic influenza preparedness. ${ }^{13}$

The article is organized in three sections. It begins by tracing the global diffusion of the Hong Kong flu, which struck in two waves. A first wave in 1968-69 was followed by a 'smoldering' second wave in 1969-70. ${ }^{14}$ While the United States was hit hardest in the first wave, other countries, such as the United Kingdom and France, experienced considerably higher mortality rates during the second wave. ${ }^{15}$ The second section examines debates about pandemic preparedness that arose out of the experience of the 1968 influenza. As Lakoff has suggested, preparedness developed from Cold War defence preoccupations of the 1950s and constituted 'a style of reasoning and a set of governmental techniques for approaching uncertain threats'. ${ }^{16}$ The third section draws on the work of the Hong Kong-based virologist Kennedy Shortridge, among others, to explore the expanded post-1968 remit of a 'long-term, wide ranging virus surveillance' and the new focus on China as a global hotspot of novel influenza viruses. ${ }^{17}$ Pandemic preparedness in the final decades of the twentieth century was 'more than just science' but required new 'multi-discipline, multi-level approaches'. ${ }^{18}$ In short, it was predicated on an ecological conceptualization of disease that understood emergence as the interaction of multiple processes: biological, environmental, social, and political. ${ }^{19}$

Despite its comparatively low morbidity and mortality figures, the Hong Kong flu was an important catalyst for the development of epidemic surveillance conceived as a 'continuous state of readiness' in anticipation of future disease threats. ${ }^{20}$ The term 'surveillance' in English meaning the act of keeping a watch or guard over a person (and later a place) - gained currency at the turn of the eighteenth and nineteenth centuries. Although the collection, management, and analysis of health data has a long history, it was not until the mid twentieth century that the word 'surveillance' was widely used within epidemiology and public health. In the post-Second World

\footnotetext{
${ }^{10}$ It has now been shown, however, that this is an urban legend: Stewart never made this pronouncement and, in fact, 'made statements to the opposite effect, clearly recognizing that infectious diseases had not been conquered'. See Brad Spellberg and Bonnie Taylor-Blake, 'On the Exoneration of Dr. William H. Stewart: Debunking an Urban Legend', Infectious Diseases of Poverty 2, no. 3 (2013), https://doi.org/10.1186/2049-9957-2-3.

${ }^{11}$ For other contributions to this reassessment, see Mark Honigsbaum, 'Revisiting the 1957 and 1968 Influenza Pandemics', Lancet 395 no. 10240 (June 2020): 1824-6; Barbara J. Jester, Timothy M. Uyeki, and Daniel B. Jernigan, 'Fifty Years of Influenza A(H3N2): Following the Pandemic of 1968', American Journal of Public Health 110, no. 5 (May 2020): 669-76.

${ }^{12}$ Edwin D. Kilbourne, 'Influenza Pandemics of the 20th Century', Emerging Infectious Diseases 12, no. 1 (January 2006): 9; see also Taubenberger and Morens, '1918 Influenza'.

${ }^{13}$ Adam Kamradt-Scott, 'The Politics of Pandemic Influenza Preparedness', in Colin McInnes, Kelley Lee, and Jeremy Youde, eds., The Oxford Handbook of Global Health Politics (Oxford: Oxford University Press, 2020), 531-50.

${ }^{14}$ Cécile Viboud, Rebecca F. Grais, Bernard A. P. Lafont, Mark A. Miller, Norio Sugaya, and Lone Simonsen, 'Multinational Impact of the 1968 Hong Kong Influenza Pandemic: Evidence for a Smoldering Pandemic', Journal of Infectious Diseases 192, no. 2 (2005): 233-48.

${ }^{15}$ Lawrence K. Altman, 'Hong Kong Flu Is Affecting Millions in Wide Areas around World', New York Times, 18 January 1970, 18; D. L. Miller, Marguerite S. Pereira, and M. Clarke, 'Epidemiology of the Hong Kong/68 Variant of Influenza A2 in Britain', British Medical Journal 1, no. 5747 (1971): 475-79.

${ }^{16}$ Andrew Lakoff, Unprepared: Global Health in a Time of Emergency (Berkeley: University of California Press, 2017$), 8$.

${ }^{17}$ Kennedy F. Shortridge, 'Bringing Pandemic Influenza to Heel: More Than Just Science', Pathology 41 (2009): 45.

${ }^{18}$ Ibid.

${ }^{19}$ Warwick Anderson, 'Natural Histories of Infectious Diseases: Ecological Vision in Twentieth-Century Biomedical Sciences', Osiris 19, no. 1 (2004): 39-61.

${ }^{20}$ Lakoff, Unprepared, 13-34; see also Andrew Lakoff, 'Preparing for the Next Emergency', Public Culture 19, no. 2 (2007): 247-71.
} 
War period, Andrew Langmuir, chief epidemiologist at the US National Communicable Disease Center (NCDC) in Atlanta - the forerunner of the Centers for Disease Control and Prevention (CDC) - was instrumental in the development of disease surveillance in the United States. During the 1950s and 1960s, Langmuir helped to widen the focus of surveillance to encompass both the detection of illness in individuals and the monitoring of disease in a population. As he defined it in an influential paper published in 1963:

Surveillance, when applied to a disease, means the continued watchfulness over the distribution and trends of incidence through the systematic collection, consolidation and evaluation of morbidity and mortality reports and other relevant data. Intrinsic in the concept is the regular dissemination of the basic data and interpretations to all who have contributed and to all others who need to know. ${ }^{21}$

Concerns about influenza - in part fuelled by the experience of 1918-19 - informed this new understanding of surveillance, which was progressively institutionalized. ${ }^{22}$ While the term 'epidemiological surveillance' gained popularity in the 1960s, suggesting that the two terms were synonymous, the scope of surveillance was broader than that of epidemiology. ${ }^{23}$

Following its foundation in 1948, the World Health Organization (WHO) had established a World Influenza Centre at the National Institute for Medical Research in London, and in 1952 it launched a Global Influenza Surveillance Network (GISN) that brought together different international laboratories. ${ }^{24}$ In a report on 'National and Global Surveillance of Communicable Diseases' prepared for the Twenty-First World Health Assembly in 1968, surveillance was characterized as 'the systematic collection and use of epidemiologic information for the planning, implementation, and assessment of disease control'. ${ }^{25}$ While surveillance as a form of 'continued watchfulness' had previously been distinguished from disease control, it was now understood to mean the gathering of actionable intelligence. ${ }^{26}$

This reinterpretation of surveillance was informed by advances in virology, including the discovery of human coronaviruses in the 1960s and - after the 1957 Asian influenza pandemic research into the origins of pandemic influenza. The influenza virus had been isolated in humans in the early 1930s and the development of experimental influenza vaccines soon followed, with the production of inactivated vaccines in the 1940s, and subsequently live-attenuated vaccines as tissue culture techniques improved. ${ }^{27}$ In the mid 1960s, the microbiologist Robert Webster and the

\footnotetext{
${ }^{21}$ Langmuir, 'Surveillance of Communicable Diseases', 182-3; see also A. D. Langmuir, 'Evolution of the Concept of Surveillance in the United States', Proceedings of the Royal Society of Medicine 64, no. 6 (1971): 681-4.

${ }^{22}$ Thedi Ziegler, Awandha Mamahit, and Nancy J. Cox, '65 Years of Influenza Surveillance by a World Health Organization-Coordinated Global Network', Influenza and Other Respiratory Viruses 12, no. 5 (2018): 558-65.

${ }^{23}$ S. Declich and A. O. Carter, 'Public Health Surveillance: Historical Origins, Methods and Evaluation', Bulletin of the World Health Organization 72, no. 2 (1994): 287; S. M. Teutsch and S. B. Thacker, 'Planning a Public Health Surveillance System', Epidemiological Bulletin 16, no. 1 (March 1995): 1.

${ }^{24}$ See M. E. Kitler, P. Gavinio, and D. Lavanchy, 'Influenza and the Work of the World Health Organization', Vaccine 20 (2002): S5-S14; Arnold S. Monto, 'Reflections on the Global Influenza Surveillance and Response System (GISRS) at 65 Years: An Expanding Framework for Influenza Detection, Prevention and Control', Influenza and Other Respiratory Viruses 12, no. 1 (2018): 10-12. The GISN was later renamed the Global Influenza Surveillance and Response System (GISRS): see Monto, 'Reflections', 10.

${ }^{25}$ World Health Organization, Report of the Technical Discussions at the 21st World Health Assembly on National and Global Surveillance of Communicable Diseases (Geneva: World Health Organization, 1968); Declich and Carter, 'Public Health Surveillance', 287.

${ }^{26}$ A. D. Langmuir, 'The Surveillance of Communicable Diseases of National Importance', New England Journal of Medicine 268, no. 4 (1963): 182-92, however, cast this reformulation in historic terms as an endeavour 'to recapture some of the old and vital spirit of William Farr'.

${ }^{27}$ Wilson Smith, C. H. Andrewes, and P. P. Laidlaw, 'A Virus Obtained from Influenza Patients', Lancet 222, no. 5732 (1933): 66-8. The influenza virus had been extracted from pigs in 1931: see R. E. Shope, 'Swine Influenza: III. Filtration Experiments and Etiology', Journal of Experimental Medicine 54 (1931): 373-85.
} 
biochemist Graeme Laver developed an influenza subunit vaccine in Australia, and at the end of the decade the first split vaccine was distributed in the United States. ${ }^{28}$

The 1960s also witnessed changes in vaccine production and management. The first flu vaccines were licensed in Europe, and in 1960 the Advisory Committee on Immunization Practices of the US Public Health Service (PHS) recommended 'annual immunization of the aged and the chronically ill'. ${ }^{29}$ In 1967, the Committee on Biological Standardization formulated the WHO's 'recommendations for the production and quality control of inactivated influenza vaccines' ${ }^{30}$

These institutional changes coincided with geopolitical shifts. In October 1949, the Chinese Communist Party under Mao seized power and proclaimed the founding of the PRC. Cold War conflict in North Korea and fears of biowarfare were important drivers for Langmuir's establishment of the Epidemic Intelligence Service (EIS) in 1951 - a few years after the Central Intelligence Agency (CIA) - as a training programme for field epidemiologists or 'disease detectives'. ${ }^{31}$

US-PRC relations were strained in the late 1960s as Mao launched the Cultural Revolution to reassert his authority and purge Chinese society of recalcitrant 'bourgeois' elements. This geopolitics coincided with an equivalent reorientation in global health. Historically, India had been identified by Western imperial powers as the global epicentre of infectious diseases, including cholera, plague, dengue, and malaria. ${ }^{32}$ The subcontinent had, of course, borne the demographic brunt of the 1918-19 pandemic. But from the mid twentieth century an increasing concern about viral diseases, including influenza, brought about a refocusing of global surveillance and virological research. Modern virology and its related environmental concerns confirmed and helped to perpetuate a view of China as the ground zero (to borrow a Cold War nuclear analogy) of viral pandemics. Through the 1960s and 1970s, southern China, in particular, was increasingly perceived within global health institutions as a stress point where converging environmental factors, including rapid urbanization and intensifying farming practices, were creating new vulnerabilities. Meanwhile, it could be argued that India began to cede its status as the epicentre of global pandemics.

\section{8: global diffusion}

On 11 July 1968, the Hong Kong Chinese-language newspaper Ming Pao reported the outbreak of an influenza-like illness in Guangdong province. ${ }^{33}$ Subsequent news stories noted flu epidemics in Szechuan, Gansu, and Shaanxi provinces. The cities of Shanghai and Wuhan were apparently affected before the infection spread south to Guangdong. ${ }^{34}$ There was no official announcement

\footnotetext{
${ }^{28}$ R. G. Webster and W. G. Laver, 'Influenza Virus Subunit Vaccines: Immunogenicity and Lack of Toxicity for Rabbits of Ether- and Detergent-Disrupted Virus', Journal of Immunology 96, no. 4 (1966): 596-605; I. Barberis, P. Myles, S. K. Ault, N. L. Bragazzi, and M. Martini, 'History and Evolution of Influenza Control Through Vaccination: From the First Monovalent Vaccine to Universal Vaccines', Journal of Preventive Medicine and Hygiene 57 (2016): E117.

${ }^{29}$ Alexander D. Langmuir, Donald Henderson, and Robert E. Serfling, 'The Epidemiological Basis for the Control of Influenza', American Journal of Public Health 54, no. 4 (1964): 563.

${ }^{30}$ World Health Organization, 'Recommendations for the Production and Control of Influenza Vaccine (Inactivated)', WHO Technical Report Series 927 (2005), annex 3.

${ }^{31}$ Alexander D. Langmuir and Justin M. Andrews, 'Biological Warfare Defense', American Journal of Public Health 42, no. 3 (1952): 235-38; Mark Pendergrast, Inside the Outbreaks: The Elite Medical Detectives of the Epidemic Intelligence Service (Boston: Houghton Mifflin Harcourt, 2010), 4.

${ }^{32}$ Although, from the late nineteenth century, Qing China was also viewed as the 'sick man of Asia'. For a brief overview of the complex ways in which China figured in Western disease imaginaries, see Robert Peckham, 'Past Pandemics Exposed China's Weaknesses', Foreign Affairs, 27 March 2020, https://www.foreignaffairs.com/articles/china/2020-03-27/pastpandemics-exposed-chinas-weaknesses.

${ }^{33}$ James M. Wilson, Marissa Iannarone, and Chunhui Wang, 'Media Reporting of the Emergence of the 1968 Influenza Pandemic in Hong Kong: Implications for Modern-Day Situational Awareness', Disaster Medicine and Public Health Preparedness 3, no. S2 (2009): S148-9.

${ }^{34}$ 'The Hong Kong Flu Began in Red China’, New York Times, 15 December 1968, 44.
} 
from the PRC confirming the epidemic, however; the PRC was not at that time a member of either the United Nations or the WHO. ${ }^{35}$

According to the Ming Pao, the flu had sparked panic buying of medicines in Guangdong. ${ }^{36}$ The situation was exacerbated by the ongoing Cultural Revolution launched by Mao. In the antiMaoist Hong Kong press, the coverage was hardly neutral, dwelling at length on the political chaos that was fuelling the epidemic. The situation in Hong Kong, a British crown colony, remained tense. To escape the political turmoil in China, thousands of immigrants had crossed the border, swelling the population of the territory to just under four million, with approximately one million people living in resettlement housing provided by the government. ${ }^{37}$ It was in these circumstances that anti-colonial riots broke out in 1967, leading to clashes between police and pro-Communist sympathizers in which fifty-one people were killed, either by police or as a result of bomb attacks. ${ }^{38}$ Hong Kong's crowded conditions also ensured that new viruses could seed rapidly and develop into 'explosive outbreaks'. ${ }^{39}$ 'When China sneezes,' an editorial in the South China Morning Post declared, 'Hong Kong catches a cold. ${ }^{\text {'0 }}$

Alarmed by information filtered from the mainland, the Hong Kong Medical and Health Department stepped up border surveillance, although there was no testing and quarantine measures were not introduced. On 13 July 1968, officials recorded a surge in patients suffering from influenza-like symptoms at government clinics. ${ }^{41} \mathrm{~A}$ heat wave was initially blamed for the spike in flu. $^{42}$ To deal with the growing number of patients, clinics were kept open over the holidays and, where possible, people were advised to stay at home and 'take aspirin, tea, lemon drinks, whisky or brandy according to taste'. ${ }^{3}$

Although the death rate was low, over the next two weeks an estimated $15 \%$ of the population was infected, or some 500,000 people. ${ }^{44}$ The Hong Kong press dubbed the infection the 'killer flu' as opposed to the 'Hong Kong flu', the name by which it was becoming known in the international news. A Hong Kong city councillor complained that the sobriquet Hong Kong flu 'was giving Hong Kong a bad name. Why don't they call it by its proper name - China flu? ${ }^{45}$ News stories emphasized the impact that the flu was having on the territory's economy, with the worst hit public utilities being the Hongkong Telephone Company and China Light \& Power. ${ }^{46}$ There was some irritation among the colony's residents that, although the flu had likely come from the PRC, it would damage Hong Kong's reputation and economy. An editorial in the South China Morning Post noted that 'Fingers of scorn will be pointing at us from many countries in a few weeks time but all we can plead is that this particular export carries no Hongkong Certificate of Origin. We have acted, unwillingly, in our old role as an entrepot for a sneeze by person or persons unknown. ${ }^{47}$

\footnotetext{
${ }^{35}$ It was not until October 1971 that the representatives of the PRC were formally recognized as 'the only legitimate representatives of China to the United Nations': Samuel S. Kim, China, the United Nations and World Order (Princeton: Princeton University Press, 1979), 347.

${ }^{36}$ Wilson, Iannarone, and Wang, 'Media Reporting of the Emergence of the 1968 Influenza Pandemic in Hong Kong', S148-9.

${ }^{37}$ W. K. Chang, 'National Influenza Experience in Hong Kong', Bulletin of the World Health Organization 41, no. 3-4-5 (1969): 349.

${ }^{38}$ Gary Ka-wai Cheung, Hong Kong's Watershed: The 1967 Riots (Hong Kong: Hong Kong University Press, 2009 ), 123.

${ }^{39}$ Chang, 'National Influenza Experience', 349.

${ }^{40 `}$ Entrepot for a Sneeze', South China Morning Post, 26 July 1968, 10.

${ }^{41}$ Chang, 'National Influenza Experience', 350.

${ }^{42 ،}$ Heat Wave Blamed for Large Number of Influenza Cases', South China Morning Post, 20 July 1968, 1.

${ }^{43}$ 'Thousands Down with Asian 'Flu', South China Morning Post, 24 July 1968, 7; 'Clinics to Open on Holidays as 'Flu Cases Rise', South China Morning Post, 26 July 1968, 1.

${ }^{44}$ Chang, 'National Influenza Experience', 349 . The figures were supplied by nine government clinics and did not include patients who attended private clinics, or those who were treated with traditional Chinese medicine; see ibid., 351 .

${ }^{45}$ 'Hong Kong Flu Began in Red China', 44.

${ }^{46}$ 'Medical Dept Hard Hit by Influenza', South China Morning Post, 25 July 1968, 1.

${ }^{47}$ Entrepot for a Sneeze', 10.
} 
In the United Kingdom, experts warned of the inadequate medical services and a shortage of vaccine'. ${ }^{48}$ The Financial Times announced in September 1968 that

The world's epidemiologists have joined the sinologists in keeping a very close watch on events in the Far East from whence another pandemic of influenza seems likely to sweep. The commercial and social disruption that can result from even a mild form of this virus infection, when whole blocks of the community - from football teams to Cabinets - succumb simultaneously, can be considerable. ${ }^{49}$

The influenza virus could now 'move with the speed of a jet airliner', according to David J. Sencer, director of the NCDC; it has been estimated that between 1968 and 1969 more than 160 million people travelled overseas by air. ${ }^{50}$ By August 1968, the flu had reached Vietnam and Singapore and the following month it was reported in the Philippines, India, Australia, and the United States. The first US cases occurred in San Diego, carried by US marines returning from the Vietnam War. The flu virus was isolated on 2 September in Atlanta, from a sample taken from a marine who had shared accommodation with a friend from Hong Kong. ${ }^{51}$

US public health experts had anticipated a mild flu for the winter of 1968-69 and were taken off-guard by news of the novel strain of influenza from Hong Kong that 'showed a marked antigenic change' from the earlier subtype A2 1957 influenza. ${ }^{52}$ In mid May, the Advisory Committee of the PHS had announced that 'little or no influenza A2 is expected to occur in the United States during the 1968-69 season, except possibly on the Pacific Coast' ${ }^{53}$ As the first cases were reported in the United States at the beginning of September, however, an emergency meeting of the committee was held. The US surgeon general declared that an epidemic was imminent, and a letter was sent out to state health officers, epidemiologists, and laboratory directors, eliciting their cooperation in 'monitoring the importation of the virus and in conducting surveillance for influenza'. ${ }^{54}$ As the PHS Advisory Committee declared: 'It is only through intensive surveillance that the true extent of the disease will be determined. ${ }^{55}$

The town of Needles in eastern San Bernardino County, California, was the first flu outbreak among a US civilian population. By October, some $40 \%$ of the town was reported ill. In Milwaukee, $43 \%$ of the population was ill, with an absenteeism rate of over $50 \%$ in adults. ${ }^{56}$ New York declared a state of emergency, although schools and businesses remained open. Despite government concerns, containment measures were not implemented. In the lull between pandemic waves, Woodstock went ahead in August 1969, attracting 400,000 people, as did the 'Moratorium March' against the Vietnam War in Washington, DC, which attracted half a million protesters.

\footnotetext{
${ }^{48 ‘}$ Asian Influenza Could Spread to Britain', Times, 30 July 1968, 8.

${ }^{49}$ David Fishlock, 'Getting Ready for the Next Asian Flu Bug', Financial Times, 14 September 1968, 13.

${ }^{50}$ 'World May Catch Hong Kong Flu', South China Morning Post, 1 November 1968, 1; Rebecca Grais, F. J. Hugh Ellis, and Gregory E. Glass, 'Assessing the Impact of Airline Travel on the Geographic Spread of Pandemic Influenza', European Journal of Epidemiology 19, no. 4 (2003): 1065.

${ }^{51}$ Robert G. Sharrar, 'National Influenza Experience in the USA, 1968-69', Bulletin of the World Health Organization 41, no. 3-4-5 (1969): 361.

${ }^{52}$ Laurie Garrett, The Coming Plague: Newly Emerging Diseases in a World out of Balance (New York: Penguin, 1994), 160; Elizabeth W. Etheridge, Sentinel for Health: A History of the Centers for Disease Control (Berkeley: University of California Press, 1992), 164.

${ }^{53}$ 'The Life of A2/Hong Kong/68', Journal of the American Medical Association 207, no. 11 (17 March 1969): 2017; 'Recommendation of the Public Health Advisory Committee on Immunization Practices', Morbidity and Mortality Weekly Report 17, no. 26 (29 June 1968): 246.

${ }^{54}$ Etheridge, Sentinel for Health, 164; Sharrar, 'National Influenza Experience in the USA', 361.

${ }^{55}$ 'Winter May Bring Flu Outbreaks Resulting from "Drift” in Virus', Journal of the American Medical Association 205, no. 12 (16 September 1968): 23 and 26.

${ }^{56}$ Frank F. Piraino, Edwin M. Brown, and Edward R. Krumbiegel, 'Outbreak of Hong Kong Influenza in Milwaukee, Winter of 1968-69’, Public Health Reports 85, no. 2 (February 1970): 148.
} 
While an editorial in the New York Times in December 1968 declared the epidemic to be 'one of the worst in the nation's history', for the most part flu stories were buried in the inside pages of newspapers. Often the news coverage was politically tinged. In declaring the disease a virus from 'Red China', discussions of the flu could be ideologically loaded.$^{57}$ In Des Moines a billboard went up that read: 'Hong Kong Flu is Unamerican! Catch something made in the U.S.A.'

In December 1968, NASA astronauts on the Apollo 8 mission - the first crewed spacecraft to leave earth's orbit - along with 1,200 personnel at Cape Kennedy, received flu shots. According to a NASA doctor, this was part of an effort "for "limited exposure" of the astronauts to cold germs before the flight'. ${ }^{58}$ In the event, Colonel Frank Borman came down with 'intestinal flu' while in orbit, experiencing diarrhoea and nausea. ${ }^{59}$ It was claimed that the astronauts had caught the illness from President Lyndon B. Johnson, whom they had met before embarking on their space mission (although the flu symptoms are more likely to have been the effects of space adaptation syndrome).

President Johnson was admitted to the Bethesda Naval Hospital suffering from a fever and an 'upper respiratory infection with a slight bronchial irritation' on 19 December. It was only with reluctance that the White House conceded that the president was suffering from the Hong Kong flu. Meanwhile, Vice-President Hubert Humphrey was recuperating from the flu in Phoenix, Arizona. ${ }^{60}$ Other well-known flu victims included the Hollywood actress Tallulah Bankhead, who succumbed to pneumonia in December 1968, and Allen Dulles, director of the CIA, who died in January 1969. The eighty-four-year-old former President Truman was admitted to hospital in Kansas City. ${ }^{61}$ By February 1969, when the epidemic was declared over, it had killed an estimated 100,000 people in the United States.

The moniker 'Mao's flu' was widely used in the media. ${ }^{62}$ In January 1969 , the British secretary of state for social services, David Ennals, responded to a question by a confused member of parliament who wondered in what way the characteristics of Mao flu can be distinguished from those of Hong Kong flu'. ${ }^{63}$ An Associated Press news report noted that 200,000 people were ill from 'Mao-Tse-tung flu' in Rome, explaining that 'the influenza virus got its nickname because it is believed to have originated in China and to have spread through Asia toward Europe via Hong Kong. ${ }^{64}$

In Europe the highest mortality occurred in December 1969. An estimated 13-17 million were infected in Italy, including the prime minister, Mariano Rumor. ${ }^{65}$ In France, it was claimed that some $25 \%$ of the population was ill, with half the workforce bedridden in some areas. French manufacturing suffered major disruptions from flu-induced absenteeism. ${ }^{66}$ The health services in both East and West Germany were also hit hard. ${ }^{67}$

\footnotetext{
${ }^{57}$ 'Hong Kong Flu Began in Red China’, 44.

58‘Apollo 8 Crew Gets Injections for Flu', New York Times, 8 December 1968, 95.

${ }^{59}$ Richard D. Lyons, 'Fliers' Conditions Closely Watched', New York Times, 23 December 1968, 26.

${ }^{60}$ Bernard Gwertzman, 'Johnson in Hospital with Cold and Fever', New York Times, 19 December 1968, 1 and 57. Elsewhere the flu was used as an excuse for other more serious illnesses, as it was in Egypt, where Nasser's heart attack was passed off as influenza (see Isabella Ginor and Gideon Remez, The Soviet-Israeli War, 1967-1973: The USSR's Military Intervention in the Egyptian-Israeli Conflict (Oxford: Oxford University Press, 2017), 125-6) - an episode that was repeated in the media (Paul Martin, 'Cairo Ousts Marxists in Purge', Times, 18 September 1969, 1).

${ }^{61 ' T r u m a n ~ G o e s ~ i n t o ~ H o s p i t a l ', ~ T i m e s, ~} 22$ February 1969, 5.

${ }^{62}$ For media coverage of the three twentieth-century influenza pandemics, see Debra E. Blakely, Mass Mediated Disease: A Case Study Analysis of Three Flu Pandemics and Public Health Policy (Lanham, MD: Lexington Books, 2006).

${ }^{63} \mathrm{See} \mathrm{https://hansard.parliament.uk/commons/1969-01-30/debates/fffcf84d-3045-438d-ad82-67d095fedc8b/Influenza.}$

64'200,000 in Rome Have Flu', New York Times, 3 November 1968, 88; see also 'Mao's Flu Arrives in the UK', Financial Times, 21 December 1968, 1; ‘Mao’s Flu Cases Confirmed', Financial Times, 10 January 1969, 1; 'Mao’s Flu Case in London', Financial Times, 11 January 1969, 1.

${ }^{65}$ Peter Nichols, '13 Million Hit by Influenza in Italy', Times, 8 December 1969, 4; Altman, 'Hong Kong Flu'.

${ }^{66}{ }^{6}$ Europe Disrupted by Flu', Financial Times, 12 December 1969, 7.

${ }^{67}$ Wilfried Witte, 'Die Grippepandemie 1968-1970: Strategien der Krisenbewältigung im getrennten Deutschland „Wodka und Himbeertee"', Deutsche Medizinische Wochenschrift 136, no. 51-2 (2011): 2664-8.
} 
The first reported case of Hong Kong flu in the United Kingdom came at the beginning of September 1968, when the young daughter of a house officer was diagnosed with the flu. ${ }^{68}$ It was not until January 1969, however, that cases were being widely reported across the United Kingdom, with the epidemic peaking in the winter of 1969-70. ${ }^{69}$ According to the Economist, the flu sparked hysteria. ${ }^{70}$ An angry general practitioner wrote to the British Medical Journal berating the newspapers and the BBC for creating confusion in the public with their 'hysterical outbursts'. ${ }^{71}$ It was reported that the pandemic threatened to overwhelm hospital services. The flu also disrupted sports activities, raised the cost of basic foods (including Christmas turkeys), and even caused delays to the Automobile Association's breakdown service. ${ }^{72}$ The cumulative effect of absenteeism led to a dip in productivity, with the closing of docks and car plants, and the postal and train services affected. ${ }^{73}$

\section{Pandemic preparedness and response}

Although US-PRC relations were strained in 1968 - a situation that created vital gaps in global surveillance - in many other contexts Cold War rivalries were offset by a surprising spirit of collaboration. This was evident in the sharing of information between the United States and the Soviet Union under Nikita Khrushchev's policy of 'peaceful coexistence'. The Soviet Union was sent sample of the new strain of the virus and apprised on its spread with 'regular exchanges of information'. In a report to the WHO, Soviet scientists noted 'the usefulness of international collaboration in the study of the epidemiology of influenza'. ${ }^{74}$

Within a fortnight of the first recorded case in Hong Kong, the virus subtype A2/Hong Kong (later designated H3N2) had been isolated by Wai-Kwan Chang, a medical officer working at the Hong Kong Government Virus Unit at Queen Mary Hospital, the University of Hong Kong (HKU)'s teaching hospital. Hong Kong was widely praised for its efficiency on the virological front in 1968, with a WHO report concluding: 'It is difficult to imagine circumstances in which the interval from arrival of specimens in a national influenza centre to the characterisation and distribution of the strain could be shortened. ${ }^{75}$ The Hong Kong laboratory had originally been set up to support the vaccination campaign for poliomyelitis in the late 1950s. ${ }^{76}$ However, in 1963 it had been designated by the WHO as a collaborating influenza centre within the GISN, an early warning system for emerging influenza viruses that collated information from centres and laboratories across the WHO network. ${ }^{77}$

Influenza had been a priority of the newly formed WHO, particular given the impact of the 1918-19 pandemic and breakthroughs in virology in the 1930s. Even before the WHO's formal establishment, the Interim Commission of the WHO had begun developing an influenza programme. ${ }^{78}$ As mentioned earlier, in 1948, the World Influenza Centre was founded at the National Institute for Medical Research in London. Two years later, the World Health

\footnotetext{
${ }^{68}$ Phillip Snashall, 'How Could I Have Done That?', British Medical Journal 339, no. 7724 (28 September 2009), https://doi. org/10.1136/bmj.

${ }^{69}$ 'Hong Kong Flu Has Reached London', Times, 11 January 1969, 1.

${ }^{70}$ 'Influenza: Feverish', Economist, 18 January 1969, 40-1.

${ }^{71}$ F. Desmond MacCarthy, 'Hong Kong Flu', British Medical Journal 1, no. 5637 (18 January 1969): 182.

${ }^{72}$ 'Down with the "Flu”', Times, 29 December 1969, 7.

${ }^{73}$ R. Reeves, 'Damage from Influenza', Financial Times, 24 March 1969, 2.

${ }^{74}$ V. M. Ždanov and I. V. Antonova, 'The Hong Kong Influenza Virus Epidemic in the USSR', Bulletin of the World Health Organization 41, no. 3-4-5 (1969): 381 and 386.

${ }^{75}$ W. C. Cockburn, P. J. Delon, and W. Ferreira, 'Origin and Progress of the 1968-69 Hong Kong Influenza Epidemic', Bulletin of the World Health Organization 41, no. 3-4-5 (1969): 348.

${ }^{76}$ Arthur E. Starling, Plague, SARS, and the Story of Medicine in Hong Kong (Hong Kong: Hong Kong University Press, 2006), 55.

${ }^{77}$ Kitler, Gavinio, and Lavanchy, 'Influenza and the Work of the World Health Organization', S5.

${ }^{78}$ Monto, 'Reflections', 10.
} 
Assembly endorsed a proposal to convoke an Expert Committee on Influenza and the inaugural meeting was held in 1952, at which the standard nomenclature for influenzas was adopted. ${ }^{79}$ An Epidemiological Surveillance Unit was also set up in the WHO's Division of Communicable Diseases, with a focus on 'the epidemiological study of disease as a dynamic process' ${ }^{80}$

After its preliminary identification in Hong Kong, the 1968 flu virus was sent for follow-up study to London on 17 July, and on 29 July it was dispatched to Atlanta. It was soon recognized as a distinct strain from previously known viruses and designated the A2/Hong Kong/68 influenza; on 16 August, the WHO issued 'a warning of its possible spread'. ${ }^{81}$ The speed with which the new virus was identified reflected advances that had taken place in molecular biology and notably in 'the ability to detect antigenic and genetic variation of influenza viruses with precision'. ${ }^{82}$ It was also evidence that the WHO's early warning system had worked. In an early report entitled 'A Coming Visitation', the Economist had stressed the importance of preparedness, noting, 'The ability to predict an epidemic with some certainty at the very least puts health authorities, hospitals, doctors and industry on the alert. But it would be even more useful if vaccination could be carried out in time to prevent an epidemic altogether.' 83

Although there was far less lead time than in 1957, the prompt identification of the virus led to the relatively swift development of a flu vaccine. ${ }^{84}$ It took just over a month from the WHO's announcement of the new strain of Hong Kong influenza in August to the production phase of the first vaccine in September 1968, following the recommendation for a monovalent vaccine containing the new A2 Hong Kong strain by the National Institute of Health (NIH)'s Division of Biologics Standards. ${ }^{85}$ The first million doses of the vaccine were made available in the United States in November 1968, with the pharmaceutical company Merck, Sharp \& Dohme pledging a further eight million doses before the end of January 1969. ${ }^{86}$ In New York City, a limited batch of vaccines was first made available in December 1968 to those over sixty-five at a Board of Health clinic on 25th Street and First Avenue. As the New York Times reported: 'The elderly came from all parts of the city. Some hobbled on two canes. Others were supported by younger relatives. Before 8 in the morning they were on the phone, asking if were true that inoculations would be given at the clinic. The little switchboard was swamped. ${ }^{187}$ However, even this was too little, too late. While the US microbiologist Maurice Hilleman ascribed the successful production of a flu vaccine to the virus's early detection by the $\mathrm{WHO}$, he also recognized that the vaccine came 'too little and too late' to be helpful in the United States. ${ }^{88}$

On the drug development front, 1968 saw the 'first opportunity to assess the effect of antiviral use during a pandemic', as well as the first systematic research in the Soviet Union into the use of interferon to control influenza. ${ }^{89}$ In February 1969, astronauts on the Soyuz 5 space mission were given interferon, with the Times of London reporting, 'The cosmonauts' living quarters were

\footnotetext{
${ }^{79}$ Kitler, Gavinio, and Lavanchy, 'Influenza and the Work of the World Health Organization', S6.

${ }^{80}$ Bernard C. K. Choi, 'The Past, Present, and Future of Public Health Surveillance', Scientifica 875253 (2012): 13, https:// doi.org/10.6064/2012/875253; Teutsch and Thacker, 'Planning a Public Health Surveillance System', 1.

${ }^{81}$ Chang, 'National Influenza Experience', 351.

${ }^{82}$ Kennedy Shortridge and Charles Stuart-Harris, 'An Influenza Epicentre?', Lancet 2, no. 8302 (1982): 813.

${ }^{83 ،}$ A Coming Visitation', Economist, 12 October 1968, 54.

${ }^{84 ‘}$ Influenza Vaccine: A Long Way from Hong Kong', Science 162, no. 3854 (8 November 1968): 651; 'The Life of A2/Hong Kong/68, Journal of the American Medical Association 207, no. 11 (17 March 1969): 2017.

${ }^{85}$ 'Influenza Vaccine, 1969-70', Morbidity and Mortality: Weekly Report 18, no. 43 (25 October 1969): 9-10; Maurice R. Hilleman, 'The Roles of Early Alert and of Adjuvant in the Control of Hong Kong Influenza by Vaccines', Bulletin of the World Health Organization 41, no. 3-4-5 (1969): 623.

${ }^{86}$ Murray Schumach, 'City Attacks Flu as 200 Get Shots', New York Times, 19 December 1968, 57.

${ }^{87} \mathrm{Ibid}$.

${ }^{88}$ Hilleman, 'Roles of Early Alert', 623.

${ }^{89}$ Jester, Uyeki, and Jernigan, 'Fifty Years of Influenza A(H3N2)', 672; V. D. Solov'ev, 'The Results of Controlled Observations on the Prophylaxis of Influenza with Interferon', Bulletin of the World Health Organization 41, no. 3-4-5 (196): 683-8.
} 
subjected to sterilization, airing and ultra-violet rays. All service staff wore gauze masks, and, with the medical staff and the cosmonauts and their stand-bys, were given doses of a new drug called Interferon intended to prevent them from catching influenza or similar ailments. ${ }^{90}$

\section{Reimagining surveillance}

'The epidemiologist must recognize that prediction of future epidemics remains a hazardous business', Langmuir remarked in the aftermath of the Hong Kong flu pandemic. 'In a way', he concluded, 'influenza predictions are like weather forecasts. As with hurricanes, pandemics can be identified and their probable course projected so that warnings can be issued. Epidemics, however, are more variable and the best that can be done is to estimate probabilities. ${ }^{.11}$ While the Hong Kong flu had revealed progress in some aspects of disease surveillance - particularly in relation to developments in virological science - it had also exposed the limitations of existing global surveillance approaches. Reflecting on the experience of 1968, Langmuir and his colleague Jere Housworth wrote: 'Many deficiencies still exist in the surveillance system that require attention if it is to serve effectively in guiding future control of influenza. ${ }^{92}$ The pandemic had also underscored 'the problems that are encountered in rapidly developing and producing sufficient quantities of vaccine incorporating a new antigen', as well as the vaccine's limited effectiveness. ${ }^{93}$

Nonetheless, the Hong Kong flu pandemic was arguably crucial to the institutionalization of a broader, integrative concept of surveillance that strove to plug the gaps that Langmuir had identified. Emerging diseases - and novel influenzas in particular - were to be placed in relation to the inter-dynamics of biological, environmental, socioeconomic, and political factors. China was to play an important role in this post-1968 reimagining of surveillance.

A January 1970 report in the New York Times, which reproduced a photograph of the new strain of the A2 virus viewed under an electron microscope, observed that 'Scientists suspect that at least three of the recent pandemics of influenza began in Mainland China. ${ }^{\text {'94 }}$ Chang, the medical officer at the Hong Kong Government Virus Unit who had first isolated the flu virus in July 1968, was more circumspect when he told an international conference: 'The Asian flu of 1957 apparently originated in the central mainland of the People's Republic of China and the epidemic of 1968 possibly could have come from the same source. ${ }^{95}$

China, rather than Spain, was further identified as the source of the 1918-19 influenza pandemic. According to Langmuir, the strain responsible for the so-called Russian influenza pandemic of 1889-90 - which the Hong Kong flu was genetically related to - had also in all probability originated in China. This was a claim made in 1891 by the physician James Cantlie. In 1888, when he was living in Hong Kong, Cantlie had by his own admission misdiagnosed an epidemic of influenza as 'tropical measles' (others claimed that it was dengue). Subsequently, however, he had recognized the disease as influenza. According to Cantlie, flu was endemic to China and the Hong Kong outbreak was 'the first recorded appearance of the modern influenza epidemic' ${ }^{96}$

These arguments were revived in the aftermath of the Hong Kong flu. Among their most articulate proponent was the Australian microbiologist Kennedy Shortridge, a key member of the Department of Microbiology at HKU from the 1970s who had been trained at the Australian National University in Canberra, where he was a peer of Webster, with whom he was later to

\footnotetext{
${ }^{90 ‘ C o s m o n a u t s ~ R e c e i v e d ~ N e w ~ A n t i-F l u ~ D r u g ’, ~ T i m e s, ~} 1$ February 1969, 6.

${ }^{91}$ A. D. Langmuir, 'Influenza: Its Epidemiology', Hospital Practice 6, no. 9 (1971): 103-8.

${ }^{92}$ Alexander D. Langmuir and Jere Housworth, 'A Critical Evaluation of Influenza Surveillance', Bulletin of the World Health Organization 41, no. 3-4-5 (1969): 393.

${ }^{93}$ 'Influenza Vaccine, 1969-70', 9-10.

${ }^{94}$ Altman, 'Hong Kong Flu'.

${ }^{95}$ Ibid.

${ }^{96}$ James Cantlie, 'The First Recorded Appearance of the Modern Influenza Epidemic', British Medical Journal 2, no. 1600 (1891): 491.
} 
collaborate. ${ }^{97}$ Shortridge would claim that his mother's stories of the 1918-19 influenza pandemic in Queensland had encouraged him to take up virology. ${ }^{98}$

From the mid 1950s there had been a growing interest in animal influenza viruses, including viruses isolated from ducks. ${ }^{99}$ After the 1957 Asian influenza pandemic, the drive to locate the origins of pandemic influenza intensified. Along with his colleague Laver, Webster was at the forefront of research into the mutation of influenza viruses in birds. On a fishing trip in New South Wales, Laver and Webster found dead mutton-birds on the seashore and hypothesized that an influenza virus had killed them. ${ }^{100}$ Investigating an epidemic among common terns on the South African coast in 1961, the virologist Walter Becker isolated an influenza A virus (H5N3) from the wild seabirds. ${ }^{101}$ A few years later, a study led by the Brazilian-British virologist Hélio Gelli Pereira established 'an antigenic relationship' between the human 1957 influenza virus and an influenza virus isolated from turkeys. ${ }^{102}$ Serological studies of wild birds subsequently demonstrated the first evidence of human flu antibodies, and 'in 1973 influenza viruses were isolated for the first time from wild migratory seabirds'. ${ }^{103}$ Webster wrote that 'These findings provided the first links in the chain of evidence that subsequently showed that the migratory aquatic birds of the world are the natural reservoirs of all influenza A viruses.' ${ }^{104}$

Shortridge brought with him to Hong Kong an ecological approach to the 'natural history' of disease that, as Warwick Anderson has argued, defined the work of Macfarlane Burnet, René Dubos, Frank Fenner, and their international networks. ${ }^{105}$ These networks were to be important for Shortridge's career in Hong Kong, where he helped to build up an expertise in emerging viral infections in the Department of Microbiology which had been created as a breakaway from the Department of Pathology in 1968.

Research at HKU focused on the surveillance of influenza virus mutations in southern China, which Shortridge described as a global 'influenza epicentre'. As he observed in a paper co-written with the British virologist Charles Stuart-Harris, 'The densely populated intensively farmed area of Southern China adjacent to Hong Kong is an ideal place for events such as interchange of viruses between host species. ${ }^{\prime 06}$ The ponds and waterways of the Pearl river hosted a rich birdlife. At the same time, traditional agricultural practices made use of ducks to 'help protect the growing rice from insect and shellfish pests and carry out weeding, intercultivation, and manuring. ${ }^{107}$ Shortridge maintained that

The closeness between man and animals could provide an ecosystem for the interaction of their viruses. Although the range of influenza viruses isolated from ducks, domestic and wild, in northern China is similar to that in the south, the opportunity for virus interaction there

\footnotetext{
${ }^{97}$ Frédéric Keck, 'Livestock Revolution and Ghostly Apparitions: South China as a Sentinel Territory for Influenza Pandemics', Current Anthropology 60 (2019): S251-9.

${ }^{98}$ Kennedy F. Shortridge, 'Foreword', in Michael Greger, Bird Flu: A Virus of Our Own Hatching (New York: Lantern Books, 2006).

${ }^{99}$ W. I. B. Beveridge, 'Unravelling the Ecology of Influenza A Virus', History and Philosophy of the Life Sciences 15, no. 1 (1993): 24 .

${ }^{100}$ Robert G. Webster, 'William Graeme Laver PhD, FRS (1929-2008)', Influenza and Other Respiratory Viruses 2, no. 5 (September 2009): i-ii, https://doi.org/10.1111/j.1750-2659.2008.00076.x.

${ }^{101}$ W. B. Becker, 'The Isolation and Classification of Tern Virus: Influenza Virus A/Tern/South Africa/1961', Journal of Hygiene 64 (1966): 309-20.

${ }^{102}$ H. G. Pereira, Bela Tumova, and R. G. Webster, 'Antigenic Relationship between Influenza A Viruses of Human and Avian Origins', Nature 215 (26 August 1967): 982-3.

${ }^{103}$ Webster, 'William Graeme Laver'.

${ }^{104}$ Ibid.

${ }^{105}$ Anderson, 'Natural Histories of Infectious Diseases'.

${ }^{106}$ Shortridge and Stuart-Harris, 'An Influenza Epicentre?', 812; see also Keck, 'Livestock Revolution and Ghostly Apparitions', S252.

${ }^{107}$ Shortridge and Stuart-Harris, ‘An Influenza Epicentre?’, 812.
} 
seems to be less certain since rice is not cultivated in the north, wheat and other cereals being more important. ${ }^{108}$

He was also to emphasize the role of pigs as vehicles for genetic reassortment in influenza ecology. ${ }^{109}$

Viewed through this surveillance optic, southern China was depicted as the place from which the next global pandemic would emerge, perhaps on a scale of the 1918-19 influenza pandemic - a view perpetuated in the media from the $1980 \mathrm{~s} .{ }^{110}$ Data from molecular epidemiology and history were presented to demonstrate that 'each year brings us closer to the next pandemic'. ${ }^{111}$ Hong Kong in this disease ecology was both part of the problem and distinct from it. On the one hand, Hong Kong was contiguous with Guangdong in the Pearl River Delta. Like the mainland, it was the haunt of roosting wild birds and viral spill-overs. On the other hand, it was a place of expertise - a strategic vantage point for monitoring suspicious viral activity in Guangdong and primed to set off global alerts. As Shortridge himself put it, 'Since the mid 1970s, Hong Kong has functioned as an influenza sentinel post for southern China, a region identified as a hypothetical epicentre for the emergence of pandemic influenza viruses. ${ }^{112}$

\section{Conclusion}

Within the history of health and indeed much of the scientific literature there is a perception of the 1950s and 1960s as being a period when 'there were few developments of note in terms of either medical science or globalization'. ${ }^{113}$ In contrast, this article has suggested that the Hong Kong flu - one of the first pandemics in which modern virological techniques were systematically deployed - revealed the progress that had been made in the decade since the Asian influenza pandemic of 1957, underscoring the importance of the WHO's GISN in monitoring for antigenic drift in influenza viruses, which was crucial for vaccine production. Walter Dowdle, the NCDC virologist, put it succinctly when he remarked, 'All that we have learned since 1957 has been applied.'114

The formation of a global influenza surveillance infrastructure through the 1950s took place in tandem with research that pointed to the close relationship between human and avian viruses. Responses to the Hong Kong flu need to be viewed in relation to growing efforts in the 1960s to develop institutions for forecasting and long-range planning, as well as advances in infectious disease surveillance and prevention, and vaccine development. ${ }^{115}$ From the late 1940s, the threat of poliomyelitis sparked panic in the United States, but by the mid 1950s Jonas Salk had developed an inactivated poliovirus vaccine, followed in the early 1960s by Albert Sabin's oral vaccine. ${ }^{116}$ During the 1957 Asian flu pandemic, the poliomyelitis surveillance programme had served as a model for response, with activities focused on collecting, collating, and evaluating reports on epidemic diseases, as well as disseminating information to health agencies and the general public. ${ }^{117}$

\footnotetext{
${ }^{108}$ Kennedy F. Shortridge, 'The 1918 “Spanish” Flu: Pearls from Swine?’, Nature Medicine 5, no. 4 (1999): 384-5.

${ }^{109}$ Shortridge and Stuart-Harris, 'An Influenza Epicentre?', 813.

${ }^{110}$ Robert Peckham, Epidemics in Modern Asia (Cambridge: Cambridge University Press, 2016), 310-11.

${ }^{111}$ Kennedy F. Shortridge, 'The Next Pandemic Influenza Virus', Lancet 346, no. 8984 (1995): 1211.

${ }^{112}$ K. F. Shortridge, 'Avian Influenza Viruses in Hong Kong: Zoonotic Considerations', in Remco S. Schrijver and G. Koch, eds., Avian Influenza: Prevention and Control (Dordrecht: Springer, 2005), 9-18; see also Frédéric Keck, Avian Reservoirs: Virus Hunters and Birdwatchers in Chinese Sentinel Posts (Durham, NC: Duke University Press, 2020), 81-7.

${ }^{113}$ Saunders-Hastings and Krewski, 'Reviewing the History of Pandemic Influenza'.

114'1957 Epidemic Contrasted: What the "Hong Kong Flu” Has Taught', Journal of the American Medical Association 207, no. 11 (17 March 1969): 2016.

${ }^{115}$ Donald N. Michael, The Unprepared Society: Planning for a Precarious Future (New York: Basic Books, 1968).

${ }^{116}$ David M. Oshinsky, Polio: An American Story (Oxford: Oxford University Press, 2005).

${ }^{117}$ Langmuir, 'Evolution of the Concept of Surveillance', 682.
} 
In 1954 , the measles virus was isolated, with a vaccine available in $1963 .{ }^{118}$ The rubella virus was isolated in 1962 and a rubella vaccine distributed from 1969. ${ }^{119}$ From 1967, the epidemiologist Donald Henderson, who had worked closely with Langmuir, led a WHO unit funded by the US Agency for International Development (USAID) that was responsible for the Smallpox Eradication Program. This involved a vaccination campaign, along with the deployment of new surveillance and containment measures. ${ }^{120}$

Although the 1968 pandemic did not trigger widespread public panic, it did serve as a catalyst for developing a new viral surveillance capacity. As the Czech epidemiologist Karel Raška noted in 1966, surveillance involved 'the epidemiological study of a disease as a dynamic process involving the ecology of the infectious agent, the host, the reservoirs, and the vectors, as well as the complex mechanisms concerned in the spread of infection and the extent to which this spread occurs'. ${ }^{121}$ At least, this was the ideal, but in reality this multifaceted surveillance was 'hampered by various practical problems and difficulties'. These included the absence of joined-up epidemiological and health services, microbiological laboratories, and ecology studies, as well as lack of interdisciplinarity. ${ }^{122}$

The global system of influenza surveillance was to be tested in the 1990s with the emergence of highly pathogenic influenza, H5N1, which crossed the species barrier for the first time in Hong Kong in 1997, infecting eighteen people and killing six. As Shortridge articulated it, that year - the year that the territory's sovereignty reverted from the United Kingdom to the PRC - 'marked the coming-of-age of animal-influenza studies'. ${ }^{123}$ Hong Kong's poultry were slaughtered and the source of the H5N1 virus was tracked down to 'geese and quail, and precursor avian [viruses]', providing 'a framework for influenza-pandemic preparedness at the baseline avian level'. ${ }^{124}$

Today, more than eight months into the COVID-19 outbreak, the origins of SARS-CoV-2 remain controversial. Did the virus originate in a Chinese laboratory or a 'wet market'? To what extent are Chinese cultural practices implicated in COVID-19's emergence? And are cavedwelling horseshoe bats in southern China the coronavirus's natural reservoir? Over half a century since the Hong Kong flu, many of the same questions are still being asked in a familiar climate of US-China tensions. The animal origins of human viral infections are again centre-stage, as is China's status as the world's viral epicentre. Despite the enormous progress in genetics, immunology, and virology, and advances in digital informatics, the implementation of an integrated approach to the management of disease emergence and transmission remains elusive. Once again, history is being evoked and government policy criticized for failing to learn from the past.

In emphasizing developments from the late 1950s to the 1970s, this article has sought to recast the dominant chronology of twentieth-century infectious disease control. It has contended that the Cold War did not signal the end of a viral era, or a shift of focus away from infections onto the new challenges posed by chronic diseases. In so arguing, it upends a late twentieth-century, postHIV/AIDS chronology; Spanish flu and SARS are set aside to offer a fresh perspective on decades that are too often passed over.

COVID-19 provides an urgent contemporary context for this reappraisal. In late May 2020 President Trump declared his intention to pull the United States out of the WHO after

\footnotetext{
${ }^{118}$ Barbara Gastel, 'Measles: A Potentially Finite History', Journal of the History of Medicine and Allied Sciences 28, no. 1 (1973): 41-2.

${ }^{119}$ Louis Z. Cooper, 'The History and Medical Consequences of Rubella', Reviews of Infectious Diseases 7, supplement 1 (March-April 1985): S2-S10.

${ }^{120}$ Donald R. Hopkins, The Greatest Killer: Smallpox in History (Chicago: University of Chicago Press, 2002; first published 1983), 304.

${ }^{121}$ K. Raška, 'National and International Surveillance of Communicable Diseases', World Health Organization Chronicle 20 (1966): 316. Raška was director of the WHO Division of Communicable Disease Control in the 1960s.

${ }^{122}$ Ibid., 319.

${ }^{123}$ Shortridge, 'Avian Influenza Viruses in Hong Kong', 9.

${ }^{124}$ Ibid.
} 
seventy-two years of membership, accusing the PRC of a 'cover-up' that had facilitated the spread of infection. Chinese officials had not only 'ignored their reporting obligations' to the WHO, but had strong-armed the WHO 'to mislead the world when the virus was first discovered by Chinese authorities'. As a result, 'Countless lives have been taken and profound economic hardship has been inflicted all around the globe.' 25

In this atmosphere of mounting tension - described as a new Cold War - there are echoes of the 1960s. Then, as now, virology was operationalized by the state and vaccine production was prioritized. As we have seen, however, there are also noticeable differences. In the 1960s and 1970s, US-led ambitions for creating an expanded global surveillance regime helped to shape the remit of the WHO. Geopolitics was instrumental in this process, of course, but health could also accommodate ideological differences. The United States could collaborate with the Soviet Union, and by the early 1970s US-China relations were improving; in 1972, President Nixon became the first US president to visit China, the same year that the PRC assumed its membership of the WHO, after joining the United Nations the previous year. ${ }^{126}$ The Declaration of Alma Ata in 1978 and the WHO's commitment of 'health for all' reflected a new vision of primary care that drew on Mao's model of the 'barefoot doctors'. In this sense, the 1960s and early 1970s, which are so often sidelined in pandemic histories, may well come to be regarded as a key period in the fleeting ascendancy of global health.

Robert Peckham is the MB Lee Professor in the Humanities and Medicine at the University of Hong Kong, where he is concurrently Chair of the Department of History and founding Director of the Centre for the Humanities and Medicine. He is also a Visiting Professor at the London School of Hygiene and Tropical Medicine. He has written widely on the history of infectious disease and epidemic control and is the author of Epidemics in Modern Asia (Cambridge University Press, 2016).

\footnotetext{
${ }^{125}$ Remarks by President Trump on Actions against China', 29 May 2020, https://www.whitehouse.gov/briefingsstatements/remarks-president-trump-actions-china/.

${ }^{126}$ Gian Luca Burci and Claude-Henri Vignes, World Health Organization (The Hague: Kluwer, 2004), 19; Kim, China, 380.
}

Cite this article: Peckham R. 2020. Viral surveillance and the 1968 Hong Kong flu pandemic. Journal of Global History 15: 444-458, doi:10.1017/S1740022820000224 